http://nv.nltu.edu.ua

https://doi.org/10.15421/40280404

Article received $11.04 .2018 \mathrm{p}$.

Article accepted $26.04 .2018 \mathrm{p}$.

T. V. Vajdanych

удК 339.5:630*8

vajdanych@nltu.edu.ua

T. В. Вайданич

Національний лісотехнічний університет Украйни, м. Львів, Украӥна

\title{
ОЦІНЮВАННЯ ПЕРСПЕКТИВНИХ МІЖНАРОДНИХ РИНКІВ ДЛЯ ОРГАНІЗАЦІЇ ЗБУТУ НЕДЕРЕВИННОЇ ПРОДУКЦІї ЛІСУ
}

Для диверсифікації експортної діяльності лісових підприємств України в напрямі продажу недеревинної лісової продукції (НДПЛ) здійснено аналіз основних світових ринків лісових ягід, лісових горіхів та меду. Виділено найбільших експортерів та імпортерів ринку за часткою і вартістю експорту (імпорту) на міжнародному ринку за допомогою інформаційних баз даних COMTRADE. Внаслідок проведеного аналізу з'ясовано динаміку середньоринкових цін на відповідних ринках у 2005-2015 р. загалом, а також проаналізовано останні тенденції світового експорту та імпорту. Виявлено відхилення цін в Україні від середньосвітових, що свідчить про цінову конкурентоспроможність вітчизняної продукції та ії̈ значний потенціал на світовому ринку. З'ясовано, що питання комерційного використання досліджуваної продукції в Україні потребують удосконалення планування, обліку та організації. Водночас проведені дослідження свідчать про недостатню увагу до аналізу, систематизації та оцінювання інформації про комерційне використання недеревинної продукції лісу з боку Державного агентства лісових ресурсів і Державної служби статистики України. Встановлено, що організоване зберігання, перероблення та продаж НДПЛ сприятиме диверсифікації експортної активності державних лісогосподарських підприємств.

Ключові слова: дослідження ринку; динаміка експорту; динаміка імпорту; частка ринку; диверсифікація експорту; середньоринкові ціни; зовнішньоторговельні бази даних; експортний потенціал; лісова продукція; товарна номенклатура ЗЕД.

Вступ. В умовах дії мораторію на експорт необробленої деревини в Україні, лісгоспам необхідно переорієнтувати свою діяльність у напрямі продажу оброблених лісоматеріалів і активно диверсифікувати експорт загалом. Прикладом такої диверсифікації є досвід лісгоспів Волині з перероблення та експорту недеревинної продукції лісу (НДПЛ) - березового соку, ягід та ін.

Дослідження та аналіз ринків для поставок диверсифікованого асортименту, умов продажу та вимог до експортування - необхідна умова вдосконалення ефективності господарювання державних лісових підприємств.

Проблеми ринку НДПЛ, різні аспекти їх значущості та використання вивчали багато науковців, зокрема, особливості використання недеревинних ресурсів дослідили E. Vidale, Da Re. R., M. Lovrik, G. Corradini, D. Pettenella (2014), В. П. Рябчук (2011), Т. М. Сторожук, Н. С. Дружинська (2015); питання еколого-економічної ефективності та світові тенденції використання - Л. О. Малик $(2006,2010)$, вагомість ринку та його значення для місцевого населення досліджували О. А. Кийко, М. М. Якуба, I. Г. Войтович, А. Shulte, U. Kies, D. Klein (2009), R. К. Bakkegaard (2014), I. П. Соловій, Т. Жула, А. Жула (2014); перспективи сталого використання - I. М. Синякевич (2008), Т. Ензель, Д. Карабчук (2016), Л. С. Осадчук, В. П. Рябчук, Р. М. Гречаник (2016); проблеми економічної оцінки ресурсів - О. В. Врублевська (2006), О. М. Адамовський, І. Пукман (2013).
Водночас питання експорту-імпорту, основних ринків збуту, динаміки світових ринкових цін на НДПЛ залишаються недостатньо вивченими.

Мета дослідження полягає у виділенні й оцінюванні перспективних міжнародних ринків для експорту НДПЛ. Для досягнення мети необхідно виокремити найбільших експортерів та імпортерів недеревинної продукції лісу та оцінити перспективи виходу українських лісгоспів на відповідні міжнародні ринки з погляду цінової перспективи.

Матеріали та методи дослідження. Аналіз динаміки збуту та середньоринкових цін на продукцію НДПЛ здійснено на основі матеріалів Державної служби статистики України, Центрального статистичного управління Польщі та баз даних зовнішньоторговельної діяльності COMTRADE (UN Comtrade Database) впродовж 2005-2015 рр., оскільки узагальнена інформація за 2016-2017 pp. неповна й уточнюється.

При цьому основну увагу приділено аналізу експортного потенціалу лісових ягід (код HS 081040: журавлина, чорниця та ін. плоди роду Vaccinium), грибів (код HS 070959: лисички, білі гриби, трюфелі та ін.) і меду (код HS 040900), оскільки цю продукцію виділено у класифікаторах в окрему групу і для організації іï перероблення, зберігання та продажу не потрібно великих внесків; попит на неї з кожним роком зростає (за умови забезпечення відповідними сертифікатами). Внаслідок

\section{Інформація про авторів:}

Вайданич Тетяна Василівна, ст. викладач, кафедра менеджменту зовнішньоекономічної діяльності.

Email: vajdanych@nltu.edu.ua

Цитування за ДСту: Вайданич Т. В. Оцінювання перспективних міжнародних ринків для організації збуту недеревинної продукції лісу. Науковий вісник НЛтУ України. Серія Економічна. 2018, т. 28, № 4. С. 26-30

Citation APA: Vajdanych, T. V. (2018). Estimation of Perspective International Markets for the Organization of Sales of Non-Timber Forest Products. Scientific Bulletin of UNFU, 28(4), 26-30. https://doi.org/10.15421/40280404 
ранжування показників за вартістю виявлено найбільших експортерів (імпортерів) ринку, визначено середньоринкові ціни.

Результати дослідження та їх обговорення. Статистика щодо НДПЛ в Україні ускладнена великою кількістю користувачів, відсутністю спеціальних статистичних форм, державних законодавчих положень та розпоряджень. На офіційних сайтах Державного агентства лісових ресурсів України, обласних управлінь лісового господарства та лісгоспів відсутні дані щодо комерційного використання НДПЛ. У щорічних національних доповідях "Про стан навколишнього природного середовища в Україні" Міністерства екології та природних ресурсів подано дані щодо обсягів заготівлі недеревинної продукції без зазначення запасів і використання лімітів. Немає відокремленої в групу інформації і на офіційних сайтах Державної служби статистики України та її регіональних відділень. Відсутність зазначених показників і недооцінювання ринкового потенціалу призводить до непрозорості лісокористування та недоотримання доходів лісогосподарствами.

У статистичній інформації Польщі окремо відображаються дані щодо вартості й обсягів закупівлі лісових ягід і грибів в розрізі регіонів та загалом (у категорії комерційне використання лісів). В Україні не має зведеної статистичної інформації стосовно цієї категорії, хоча запаси лісової продукції є достатньо великі й більшу їх частину використовують для отримання доходу місцеві мешканці. Організація перероблення НДПЛ може стати дієвим інструментом диверсифікації експорту загалом і переорієнтації від експорту сировини і необробленої деревини до експорту переробленої продукції.

Дослідження свідчать, що в Польщі ринок лісових ягід $\epsilon$ організованим і прозорим, середні експортно-імпортні ціни значно вищі, ніж в Україні (рисунок).

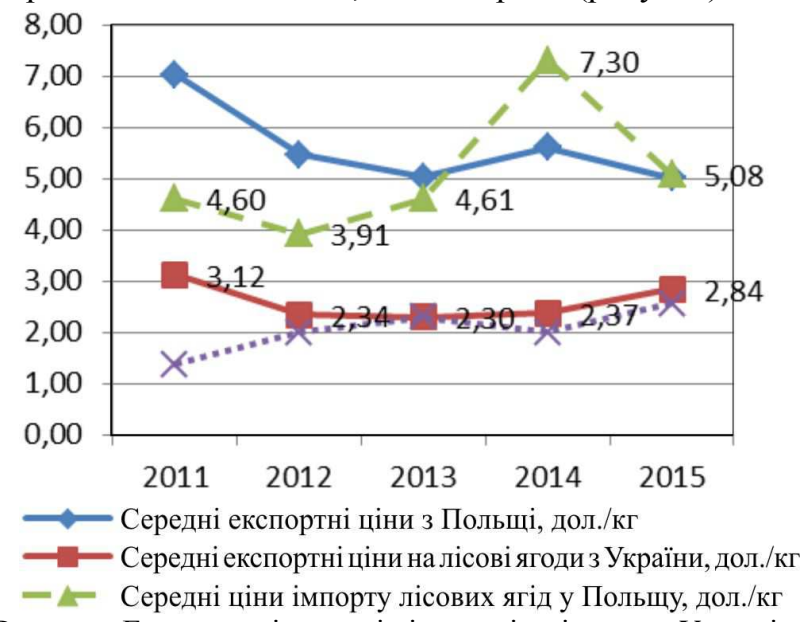

Рисунок. Експортно-імпортні ціни на лісові ягоди в Україні та Польщі (розрахував автор за даними COMTRADE i Glówny Urzad Statystyczny)

Польща у 2014 р. імпортувала лісові ягоди значно дорожче, ніж експортувала. У 2015 р. експортно-імпортні ціни в Польщі в 1,8 раза перевищували ціни в Україні.

Табл. 1. Динаміка і структура світового експорту найбілыших експортерів лісових ягід (код HS 081040: журавлина, чорниця, та ін. плоди роду Vaccinium)

\begin{tabular}{|c|c|c|c|c|c|c|c|c|}
\hline \multirow{2}{*}{$\begin{array}{l}\text { № } \\
3 / \Pi\end{array}$} & \multicolumn{4}{|c|}{$2005 \mathrm{p}}$. & \multicolumn{4}{|c|}{$2015 \mathrm{p}}$. \\
\hline & $\begin{array}{c}\text { країна- } \\
\text { експортер }\end{array}$ & $\begin{array}{c}\text { вартість експорту, } \\
\text { млн дол. }\end{array}$ & $\begin{array}{c}\text { середня ціна, } \\
\text { дол./кг }\end{array}$ & $\begin{array}{c}\text { частка } \\
\text { ринку, \% }\end{array}$ & $\begin{array}{c}\text { країна- } \\
\text { експортер }\end{array}$ & $\begin{array}{c}\text { вартість експорту, } \\
\text { млн дол. }\end{array}$ & $\begin{array}{c}\text { середня ціна, } \\
\text { дол./кг }\end{array}$ & $\begin{array}{c}\text { частка } \\
\text { ринку, \% }\end{array}$ \\
\hline 1 & Чилі & 104,594 & 8,76 & 26 & Канада & 548,113 & 6,29 & 29 \\
\hline 2 & Канада & 85,918 & 1,53 & 22 & Чилі & 231,486 & 7,65 & 12 \\
\hline 3 & США & 73,886 & 1,95 & 19 & США & 185,929 & 1,74 & 10 \\
\hline 4 & Аргентина & 28,372 & 10,43 & 7 & Іспанія & 181,803 & 4,32 & 10 \\
\hline 5 & Нідерланди & 17,778 & 9,36 & 4 & Нідерланди & 154,083 & 8,86 & 8 \\
\hline 7 & Польща & 11,360 & 4,34 & 3 & Польща & 95,804 & 9,38 & 5 \\
\hline \multicolumn{2}{|c|}{ Інші, зокрема } & 41,34 & 2,78 & 10 & Інші, зокрема & 196,78 & 5,50 & 11 \\
\hline \multicolumn{2}{|r|}{ Україна } & 3,675 & 1,69 & 0,92 & Україна & 2,487 & 2,84 & 0,13 \\
\hline \multicolumn{2}{|r|}{ Всього } & 397,332 & 2,95 & 100 & Всього & 1859,759 & 5,00 & 100 \\
\hline
\end{tabular}

Загалом експорт лісових ягід у 2015 р. зріс у 4,5 раза (табл. 1), порівняно з 2005 р., і становив 1859,759 млн дол. США. Найбільшими експортерами $є$ Канада (29\%), Чилі (12\%), США (10\%), Іспанія (10\%), Нідерланди $(8 \%)$ та ін. Частка експорту 10 найбільших експортерів становить 89 \%. Частка України в загальносвітовому експорті мізерна і становить всього 0,13\%. Стабільно збільшує свою частку у світовому експорті
Польща - від 3 \% (11,36 млн дол. США) до 5 \% (95,804 млн дол.).

За останніми даними, експорт із Польщі знизився на 17 \% (UN Comtrade Database, 2016), експорт з України зріс у 3,41 раза (UN Comtrade Database, 2017). Аналіз показників експорту свідчить про стабільне зростання попиту на ринку лісових ягід, проте успіх основних експортерів зумовлений саме плантаційним вирощуванням та організованими закупівлями.

Табл. 2. Динаміка і структура світового імпорту найбілыших імпортерів лісових ягід (код HS 081040: журавлина, чорниця, та ін. плоди роду Vaccinium)

\begin{tabular}{|c|c|c|c|c|c|c|c|c|}
\hline \multirow{2}{*}{$\begin{array}{c}\text { № } \\
3 / \Pi\end{array}$} & \multicolumn{3}{|c|}{2005 р. } & \multicolumn{5}{c|}{2015 р. } \\
\cline { 2 - 9 } & $\begin{array}{c}\text { країна- } \\
\text { іпортер }\end{array}$ & $\begin{array}{c}\text { вартість імпорту, } \\
\text { млн дол. }\end{array}$ & $\begin{array}{c}\text { середня ціна, } \\
\text { дол./кг }\end{array}$ & $\begin{array}{c}\text { частка } \\
\text { ринку, } \%\end{array}$ & $\begin{array}{c}\text { країна- } \\
\text { імпортер }\end{array}$ & $\begin{array}{c}\text { вартість імпорту, } \\
\text { млн дол. }\end{array}$ & $\begin{array}{c}\text { середня ціна, } \\
\text { дол./кг }\end{array}$ & $\begin{array}{c}\text { частка } \\
\text { ринку, \% }\end{array}$ \\
\hline 1 & США & 163,389 & 2,46 & 42 & США & 797,334 & 4,26 & 40 \\
\hline 2 & $\begin{array}{c}\text { Великобри- } \\
\text { танія }\end{array}$ & 69,112 & 11,53 & 18 & $\begin{array}{c}\text { Великобрита- } \\
\text { нія }\end{array}$ & 220,801 & 7,37 & 11 \\
\hline 3 & Канада & 47,033 & 2,00 & 12 & Канада & 167,394 & 4,45 & 8 \\
\hline 4 & Японія & 20,967 & 13,34 & 5 & Нідерланди & 162,566 & 7,24 & 8 \\
\hline 5 & Німеччина & 12,202 & 4,83 & 3 & Німеччина & 126,228 & 6,69 & 6 \\
\hline Інші, зокрема & 39,23 & 2,86 & 10 & Інші, зокрема & 284,26 & 6,05 & 14 \\
\hline \multicolumn{2}{|c|}{ Україна } & 0,009 & 0,23 & 0,002 & Україна & 0,051 & 2,56 & 0,003 \\
\hline \multicolumn{2}{|c|}{ Всього } & 388,063 & 3,13 & 100 & Всього & 1978,761 & 5,38 & 100 \\
\hline
\end{tabular}


Найбільшими імпортерами лісових ягід є США (40\% світового імпорту), Великобританія (11\%), Канада (8 \%), Нідерланди (8 \%), Німеччина (6 \%), Китай, Іспанія, Норвегія, Швейцарія та Бельгія. Частка цих 10 країн становить 86 \% світового імпорту. Це - найпри- вабливіші ринки для експорту українських лісових ягід. Отож, Канада, США і Нідерланди водночас є найбільшими експортерами та імпортерами ягід (табл. 3).

Ринок грибів зростає значно меншими темпами.

Табл. 3. Динаміка і структура світового експорту найбілыших експортерів лісових грибів (код HS 070959: лисички, білі гриби, трюфелі та ін.)

\begin{tabular}{|c|c|c|c|c|c|c|c|c|}
\hline \multirow{2}{*}{$№$} & \multicolumn{3}{c|}{2005 р. } & \multicolumn{4}{c|}{2015 р. } \\
\cline { 2 - 9 } & $\begin{array}{c}\text { країна-ек- } \\
\text { спортер }\end{array}$ & $\begin{array}{c}\text { вартість експорту, } \\
\text { млн дол. }\end{array}$ & $\begin{array}{c}\text { сер. ціна, } \\
\text { дол./кг }\end{array}$ & $\begin{array}{c}\text { частка } \\
\text { ринку, \% }\end{array}$ & $\begin{array}{c}\text { країна- } \\
\text { експортер }\end{array}$ & $\begin{array}{c}\text { вартість експорту, } \\
\text { млн дол. }\end{array}$ & $\begin{array}{c}\text { сер. ціна, } \\
\text { дол./кг }\end{array}$ & $\begin{array}{c}\text { частка } \\
\text { ринку, \% }\end{array}$ \\
\hline 1 & Китай & 129,797 & 3,19 & 26 & Китай & 151,010 & 3,00 & 23 \\
\hline 2 & Польща & 38,153 & 2,44 & 22 & Нідерланди & 63,577 & 3,36 & 10 \\
\hline 3 & Нідерланди & 29,777 & 3,16 & 19 & Італія & 60,586 & 22,49 & 9 \\
\hline 4 & Румунія & 24,728 & 6,52 & 7 & Р. Корея & 36,194 & 2,46 & 6 \\
\hline 5 & Литва & 23,274 & 5,70 & 4 & Румунія & 35,904 & 8,65 & 6 \\
\hline 6 & Франція & 16,985 & 8,48 & 3 & Польща & 34,478 & 2,38 & 5 \\
\hline Інші, зокрема & 76,30 & 6,27 & 6,27 & Інші, зокрема & 163,67 & 3,57 & 25 \\
\hline \multicolumn{2}{|c|}{ Україна } & - & - & - & Україна & 0,811 & 4,38 & 0,12 \\
\hline \multicolumn{2}{|c|}{ Всього } & 396,792 & 3,77 & 100 & Всього & 652,376 & 3,82 & 100 \\
\hline
\end{tabular}

У 2015 р. (за останні 10 років) вартість експорту грибів зросла на $64 \%$. Основними експортерами є Китай (23\%), Нідерланди (10\%), Італія (9\%), Республіка Корея (6 \%), Румунія, Польща та ін. Польща експортує гриби в промислових масштабах і ввійшла в число найбільших експортерів внаслідок організації плантаційного вирощування. Україна у 2015 р. експортувала гриби за ціною 4,38 дол./кг. Середньосвітові ціни ста- ном на 2015 р. становили 3,82 дол./кг. Високі ціни окремих експортерів пов'язані із ціною на трюфелі.

У 2017 р. експорт грибів з України зріс у 4,26 раза, порівняно із 2015 р. Істотний приріст експорту може забезпечити організування плантаційного вирощування, що практикують найбільші експортери світу і зусилля зі зберігання та транспортування їх у свіжому вигляді.

Табл. 4. Динаміка і структура світового імпорту найбільших імпортерів лісових грибів (код HS 070959: лисички, білі гриби, трюфелі та ін.)

\begin{tabular}{|c|c|c|c|c|c|c|c|c|}
\hline \multirow{2}{*}{$\begin{array}{l}\text { № } \\
\text { 3/ח }\end{array}$} & \multicolumn{4}{|c|}{2005 p. } & \multicolumn{4}{|c|}{$2015 \mathrm{p}$. } \\
\hline & країна-імпортер & $\begin{array}{l}\text { вартість імпорту, } \\
\text { млн. дол. }\end{array}$ & $\begin{array}{l}\text { сер. ціна, } \\
\text { дол./кг }\end{array}$ & $\begin{array}{c}\text { частка } \\
\text { ринку, \% }\end{array}$ & країна-імпортер & \begin{tabular}{|c|} 
вартість імпорту, \\
млн. дол.
\end{tabular} & $\begin{array}{l}\text { сер. ціна, } \\
\text { дол./кг }\end{array}$ & $\begin{array}{c}\text { частка } \\
\text { ринку, \% }\end{array}$ \\
\hline 1 & Японія & 153,934 & 6,01 & 33 & Німеччина & 88,942 & 3,00 & 23 \\
\hline 2 & Німеччина & 62,505 & 4,25 & 14 & Франція & 73,153 & 3,36 & 10 \\
\hline 3 & Франція & 44,343 & 3,62 & 10 & Японія & 59,121 & 22,49 & 9 \\
\hline 4 & Італія & 41,327 & 6,65 & 9 & Великобританія & 54,562 & 2,46 & 6 \\
\hline 5 & Великобританія & 32,018 & 1,39 & 7 & Італія & 52,486 & 8,65 & 6 \\
\hline & Інші, зокрема & 57,64 & 2,80 & 13 & Інші, зокрема & 233,39 & 4,04 & 25 \\
\hline & Україна & - & - & $\begin{array}{llll}- & & & \end{array}$ & Україна & 0,008 & 54,28 & 0,001 \\
\hline & Всього & 459,659 & 3,76 & 100 & Всього & 708,297 & 3,78 & 100 \\
\hline
\end{tabular}

Найпривабливішими ринками, як свідчить аналіз світового імпорту, є ринки Німеччини (23\% світового імпорту), Франції, Японії, Великобританії, Італії, США, Таїланду, Республіки Кореї та ін. Середні ціни на ринку за 10 років майже не змінились. Україна імпортує грибів усього на 8 тис. дол. США (табл. 4).

Ринок меду серед продукції побічного лісокористування $є$ найпривабливішим 3 маркетингового погляду (табл. 5).

Табл. 5. Динаміка і структура світового експорту найбілыших експортерів меду (код НS 040900)

\begin{tabular}{|c|c|c|c|c|c|c|c|c|}
\hline \multirow{2}{*}{$\begin{array}{l}\text { № } \\
\text { 3/ח }\end{array}$} & \multicolumn{4}{|c|}{$2005 \mathrm{p}}$. & \multicolumn{4}{|c|}{$2015 \mathrm{p}}$. \\
\hline & $\begin{array}{c}\text { країна- } \\
\text { експортер }\end{array}$ & $\begin{array}{c}\text { вартість експорту, } \\
\text { млн дол. }\end{array}$ & $\begin{array}{c}\text { сер. ціна, } \\
\text { дол./кг }\end{array}$ & $\begin{array}{c}\text { частка } \\
\text { ринку, \% }\end{array}$ & $\begin{array}{c}\text { країна- } \\
\text { експортер }\end{array}$ & $\begin{array}{c}\text { вартість експор- } \\
\text { ту, млн дол. }\end{array}$ & $\begin{array}{l}\text { сер. ціна, } \\
\text { дол./кг }\end{array}$ & $\begin{array}{c}\text { частка } \\
\text { ринку, \% }\end{array}$ \\
\hline 1 & Аргентина & 128,463 & 1,19 & 18 & Китай & 288,668 & 1,99 & 13 \\
\hline 2 & Китай & 87,629 & 0,99 & 12 & Нова Зеландія & 200,409 & 18,83 & 9 \\
\hline 3 & Німеччина & 80,210 & 3,07 & 11 & Аргентина & 163,829 & 3,59 & 8 \\
\hline 4 & Угорщина & 42,614 & 2,25 & 6 & Мексика & 155,986 & 3,70 & 7 \\
\hline 5 & Мексика & 31,836 & 1,67 & 4 & Німеччина & 139,402 & 5,52 & 6 \\
\hline 8 & Канада & 25,050 & 2,02 & 4 & Україна & 83,982 & 2,33 & 4 \\
\hline \multicolumn{2}{|c|}{ Інші, зокрема } & 220,36 & 2,15 & 31 & Інші, зокрема & 763,47 & 4,05 & 35 \\
\hline \multicolumn{2}{|r|}{ Україна } & 5,152 & 1,35 & 0,73 & Україна & 83,982 & 2,33 & 3,8 \\
\hline & Всього & 708,459 & 1,72 & 100 & Всього & 2181,378 & 3,57 & 100 \\
\hline
\end{tabular}

Лісовий мед дає невичерпні рекламні та інформаційні можливості, оскільки на світовому ринку спостерігають стійке зростання попиту на органічну продукцію. Про перспективність ринку меду свідчить зростання світових обсягів експорту за 10 років у 2015 р. в 3 рази.

Найбільшим експортером меду є Китай (13\% світового експорту), що продає мед за найнижчими ринкови- ми цінами (майже 2 дол./кг), порівняно 3 десяткою інших великих експортерів. Найдорожчий мед продає Нова Зеландія - 18, 83 дол./кг. За 10 років середні ринкові ціни на мед зросли від 1,72 дол./кг до 3,57 дол./кг. У десятці найбільших експортерів - Аргентина (8\%), Мексика (7\%), Німеччина (6\%), Індія (6\%), Іспанія (5\%). Україна входить до десятки найбільших експортерів і посідає 8 місце за доходами від експорту меду. 
За 10 років експорт меду з України зріс у 16,3 раза. У 2017 р. в Україні зростання надходжень від експорту меду становило 59 \%, порівняно з 2015 р. Проте експортний потенціал щодо меду в Україні є значно вищим і використовують не повністю через квоти, встановлені ЄС.

Табл. 6. Динаміка і структура світового імпорту найбілыших імпортерів меду (код HS 040900)

\begin{tabular}{|c|c|c|c|c|c|c|c|c|}
\hline \multirow[b]{2}{*}{$\begin{array}{l}\text { № } \\
3 / \Pi\end{array}$} & \multicolumn{4}{|c|}{$2005 \mathrm{p}}$. & \multicolumn{4}{|c|}{$2015 \mathrm{p}}$. \\
\hline & країна-імпортер & \begin{tabular}{|c|} 
вартість імпор- \\
ту, млн дол.
\end{tabular} & $\begin{array}{c}\text { сер. } \\
\text { ціна, дол./кг }\end{array}$ & $\begin{array}{c}\text { частка } \\
\text { ринку, \% }\end{array}$ & країна-імпортер & $\begin{array}{c}\text { вартість імпорту, } \\
\text { млн дол. }\end{array}$ & $\begin{array}{l}\text { сер. ціна, } \\
\text { дол./кг }\end{array}$ & $\begin{array}{c}\text { частка } \\
\text { ринку, \% }\end{array}$ \\
\hline 1 & Німеччина & 167,654 & 1,75 & 22 & США & 605,325 & 3,45 & 27 \\
\hline 2 & США & 138,546 & 1,31 & 19 & Німеччина & 317,294 & 3,73 & 14 \\
\hline 3 & Великобританія & 63,978 & 2,23 & 9 & Великобританія & 129,654 & 3,12 & 6 \\
\hline 4 & Японія & 57,540 & 1,33 & 8 & Франція & 137,826 & 3,84 & 6 \\
\hline 5 & Франція & 43,675 & 2,25 & 6 & Японія & 117,643 & 3,25 & 5 \\
\hline & Інші, зокрема & 157,42 & 2,28 & 21 & Інші, зокрема & 589,07 & 3,66 & 26 \\
\hline & Україна & 0,075 & 1,19 & 0,01 & Україна & 0,098 & 5,86 & 0,004 \\
\hline & Всього & 746,584 & 1,79 & 100 & Всього & 2274,922 & 3,54 & 100 \\
\hline
\end{tabular}

Найпривабливішими ринками щодо ємності імпорту є ринки США (27\%), Німеччини (14\%), Франції, Великобританії, Японії. На особливу увагу вітчизняних експортерів заслуговують ринки США, Японії, Китаю і Саудівської Аравії. Середні імпортні ціни у 2015 р. становили 3,54 дол./кг. Найдорожче можна продати мед у Китай. Україна імпортує незначний обсяг меду, причому за завищеними ринковими цінами (табл. 6).

Висновки. Проведений аналіз свідчить про значний потенціал ринків НДПЛ, що використовується вкрай неефективно. Насамперед необхідно активізувати зусилля щодо залучення інвестицій для організації плантаційного вирощування, збирання та перероблення продукції. Також важливо забезпечити прозорість вітчизняного ринку за допомогою статистичної інформації про потенціал, ліміти, обсяги та вартість комерційного використання НДПЛ у динаміці.

\section{Перелік використаних джерел}

Bakkegaard, R. K. (2014). Regional Analysis of forest product use and dependence amongst rural households in South Caucasus, Eastern Europe and Russia. ENPI-FLEG. Retrieved from: http://www.enpi-fleg.org/site/assets/files/1733/regional_report_forest_dependency_feb_2015.pdf.

Chufin, L. G., \& Malyk, L. O. (2010). World tendencies of trade of unarboreal forest products. Scientific Bulletin of UNFU, 16(5), 131137. Retrieved from: http://nltu.edu.ua/nv/Archive/2010/20_8/260_Czufin_20_8.pdf. [In Ukrainian].

Kiyko, O. A., Yakuba, I. G., Voytovich, I. G., Shulte, Andreas, Kies, Uwe, Klein, Dajana. (2009). Cluster analysis of the forest complex of the Carpathian region of Ukraine. Scientific Bulletin of UNFU, 19(9), 20-28. Retrieved from: https://www.researchgate.net/publication/237483557_Cluster_analysis_of the forest_sector_in the Carpathian_Region_of UUkraine. [In Ukrainian].

Osadchuk, L. S., Riabchuk, V. P., \& Hrechanyk, R. M. (2016). Role of non-timber Forest Resources in sustainable Forest Management in Ukraine. Proceedings of the Forestry Academy of Sciences of Ukraine, 14, 92-97. https://doi.org/10.15421/411612. [In Ukrainian].

Skup owoców. (2018). Skup owoców i grzybów leśnych. Gospodarcze wykorzystanie lasu. Rolnictwo, leśnictwo i łowiectwo. [Purchase of fruit and forest mushrooms. Economic use of the forest. Agriculture, forestry and hunting]. Retrieved from: https://bdl.stat.gov.pl/BDL/dane/podgrup/wymiary. [In Polish].

Soloviy, I. (2016). Evaluation of forest ecosystem services provided by forests of Ukraine and proposals on PES mechanisms. ENPI FLEG. Nov. 2016. Retrieved from: http://sfmu.org.ua/files/Soloviy_2016b.pdf. [In Ukrainian].

Storozhuk, T. M., \& Druzhynska, N. S. (2015). Nederevni lisovi resursy. Scientific Bulletin of UNFU, 10, 161-163. [In Ukrainian].

Syniakevych, I. M., Solovii, I. P., \& Vrublevska, O. V. (Eds.). (2008). Lisova polityka: teoriia i praktyka. Lviv. [In Ukrainian].

UN Comtrade Database. (2018). Retrieved from: http://comtrade.un.org/data/.

Vidale, E., Da Re, R., Lovrik, M., Corradini, G., \& Pettenella, D. (2014). International trade of the NWFP: any opportunity for the Italian forest sector?. In: Proceedings of the Second International Congress of Silviculture. Designing the future of the forestry sector. Florence, 26.29 November, 2014. Firenze: Accademia Italiana di $\begin{array}{lllll}\text { Scienze Forestali. } & \text { Vol. 2, p. } & \text { 734-753. }\end{array}$ https://doi.org/10.4129/2cis-ev-int

Vrublevska, O. V., \& Sirko, N. I. (2006). Economic Evaluation of Non-Wood Forest Resources (Case-study for the Forest Land of the "Brody State Forestry Enterprise"). Scientific Bulletin of UNFU, 16(5), 131-137. Retrieved from: http://nltu.edu.ua/nv/Archive/2006/16 5/131 Wrublewska 16 5.pdf. [In Ukrainian].

Zhyla, T., \& Żhyla, $\bar{A}$. (2016). Doslidzhennia zalezhnosti mistsevoho naselennia vid posluh lisovykh ekosystem. ENPI FLEG. Retrieved from: http://www.fleg.org.ua/wp-content/uploads/2016/12/Report_FD_study_2016_ukr.pdf. [In Ukrainian].

Zovnishnia torhivlia. (2018). Zovnishnia torhivlia okremymy vydamy tovariv za krainamy svitu. Derzhavna sluzhba statystyky Ukrainy (State Statistics Service of Ukraine). Retrieved from: http://www.ukrstat.gov.ua/. [In Ukrainian].

T. В. Вайданич

Национальный лесотехнический университет Украины, г. Львов, Украина

\section{ОЦЕНКА ПЕРСПЕКТИВНЫХ МЕЖДУНАРОДНЫХ РЫНКОВ ДЛЯ ОРГАНИЗАЦИИ СБЫТА НЕДРЕВЕСНОЙ ПРОДУКЦИИ ЛЕСА}

Для диверсификации экспортной деятельности лесных предприятий Украины в направлении сбыта недревесной продукции леса (НДПЛ), осуществлен анализ основных мировых рынков лесных ягод, лесных орехов и мёда. Выделены крупнейшие экспортёры и импортёры рынка по долевому участию и стоимости экспорта (импорта) на международном рынке с помощью информационных баз данных COMTRADE. Вследствие проведенного анализа выяснена динамика среднерыночных цен на соответствующих рынках в 2005-2015 гг. в целом, а также проанализированы последние тенденции мирового экспорта и импорта. Выявлены значительные отклонения цен в Украине от мировых, что свидетельствует о ценовой конкурентоспособности отечественной продукции и ее потенциальных возможностях на мировом рынке. Выяснено, что вопрос коммерческого использования исследуемой продукции в Украине требует совершенствования планирования, учета и организации. В то же время, проведенные исследования свидетельствуют о недостаточном внимании к анализу, систематизации и оценке информации о НДПЛ со стороны Государственного агентства лесных ресурсов и Государственной службы статис- 
тики Украины. Установлено, что организованное хранение, переработка и продажа НДПЛ будет способствовать диверсификации экспортной активности государственных лесохозяйственных предприятий.

Ключевые слова: исследование рынка; динамика экспорта; динамика импорта; долевое участие рынка; диверсификация экспорта; среднерыночные цены; внешнеторговые базы данных; экспортный потенциал; лесная продукция; товарная номенклатура ВЭД.

T. V. Vajdanych

Ukrainian National Forestry University, Lviv, Ukraine

\section{ESTIMATION OF PERSPECTIVE INTERNATIONAL MARKETS FOR THE ORGANIZATION OF SALES OF NON-TIMBER FOREST PRODUCTS}

The market for non-timbered forest products (NTFPs) in Ukraine needs transparent statistical and financial accounting regarding limits for usage, average market prices, sales volumes and processing. State forestry enterprises in Ukraine need reliable information about the market potential of the NTFPs in order to diversify exports. The main markets for such non-timber forest products (NTFPs) as the forest berries, hazelnuts and honey were investigated in this paper. The largest exporters and importers by market share and export (import) value are outlined on the basis of the international COMTRADE trading databases. Such analysis helps determine the dynamics of average market prices in relevant markets in 2005-2015. Significant deviations of import and export prices in Ukraine from the average world prices are discovered, which testifies the price competitiveness of domestic products and its considerable potential in the world market. The fact that the commercial usage of the mentioned NTFPs in Ukraine needs the improvement of planning, accounting and organization is outlined in the article. All conducted research indicates the insufficient attention from the State Agency of Forest Resources of Ukraine and the State Statistics Service of Ukraine to the analysis, systematization and evaluation of information about the usage of NTFPs. Such underestimating of the value and scale of market potential leads to a lack of transparency in the usage of the forest raw material base and reduces the financial value of forestry activities. An example of statistical information presentation in Poland about the commercial forests usage is outlined as well as the proposals of such registration in Ukraine on both the state and regional levels are substantiated. The organized storage, processing and sale of NTFPs will promote the diversification of export activity of state forest enterprises from the sale of unprocessed timber to the sale of non-timbered forest products.

Keywords: market research; export dynamics; import dynamics; market share; export diversification; average market prices; foreign trade databases; export potential; forest products; non-timbered forest products; commodity nomenclature. 